\title{
Forage Quality of Plant Species Consumed by Capybaras (Hydrochoerus hydrochaeris) in the Paraná River Delta, Argentina
}

\author{
María J. Corriale, ${ }^{1}$ Santiago M. Arias, ${ }^{2}$ and Rubén D. Quintana ${ }^{3}$ \\ Authors are ${ }^{1}$ Research Fellow, Consejo Nacional de Investigaciones Científicas y Tecnológicas (CONICET), ${ }^{2}$ Technical Professional Secretaría de \\ Ambiente y Desarrollo Sustentable, and ${ }^{3}$ Researcher, CONICET, and Associated Professor Facultad de Ciencias Exactas y Naturales (FCEyN), \\ Universidad de Buenos Aires (UBA), Grupo de Investigaciones sobre Ecología de Humedales (GIEH), Laboratorio de Ecología Regional, Departamento \\ de Ecología, Genética y Evolución, FCEyN, UBA, Pab II, Ciudad Universitaria, C1428EHA Buenos Aires, Argentina.
}

\begin{abstract}
The capybara (Hydrochoerus hydrochaeris) is a selective herbivore that may show a preference for certain plant species. Such a preference is likely to be explained by the nutritional benefits hypothesis, stating that the nutritional value of species selected by capybaras is higher than that of avoided ones. Therefore, the objectives of this work are to evaluate the nutritional value of the plant species eaten by capybaras in the Lower Delta of the Paraná River, and to test the nutritional benefits hypothesis by analyzing forage quality. Samples of consumed plant species were collected from habitats located in the study area. We also collected plant species that are very abundant in the field but absent in the capybara's diet, some of which are consumed by other native herbivores such as coypus (Myocastor coypus). Their nutritional quality was analyzed by estimating the following variables: water content, ash percentage, percentage of organic matter, acid detergent fiber, nitrogen percentage, crude protein, and caloric energy. The protein to fiber ratio was calculated and the water content was determined. The species consumed and not consumed by capybaras had a similar nutritional composition for all the variables analyzed $(P<0.05)$. A similar result was observed when comparing within consumed species, except for the caloric energy content, which was significantly higher in species consumed in greater proportion than availability $(P<0.05)$. Water content was at its minimum in species consumed in greater proportion than availability, and at its maximum in unconsumed species. No significant differences were found between consumed Poaceae and the rest of the consumed plant species for any of the analyzed variables. Diet selection by capybaras in the studied area may only be partially related to nutritional quality, and there would be other factors involved in foraging, such as physiological mechanisms of the animal or chemical and structural characteristics of food.
\end{abstract}

\section{Resumen}

El carpincho (Hydrochoerus hydrochaeris) es un herbívoro selectivo que puede presentar preferencia por ciertas especies vegetales. Tal preferencia forrajera posiblemente se explique a través de la hipótesis de beneficios nutricionales, la cual plantea que las especies seleccionadas presentan un valor nutricional mayor que aquellas evitadas. Por consiguiente, los objetivos del presente estudio fueron evaluar el valor nutricional de las especies vegetales consumidas por el carpincho en el Bajo Delta del Río Paraná y poner a prueba la hipótesis de beneficios nutricionales a través del análisis de la calidad del forraje. Se colectaron muestras de especies vegetales consumidas por el carpincho en los distintos tipos de hábitats localizados en el área de estudio. También se colectaron muestras de plantas que eran muy abundantes en el campo pero se encontraban ausentes en la dieta del carpincho pero que son consumidas por otros herbívoros nativos como el coipo (Myocastor coypus). La calidad nutricional del forraje fue evaluada a través del análisis de las siguientes variables: contenido de agua, porcentaje de cenizas, porcentaje de material orgánica, fibra detergente ácido, porcentaje de nitrógeno, contenido de proteína bruta y energía calórica. Se estimó además la relación proténa/fibra y el contenido de agua. Tanto las especies consumidas como las no consumidas por los carpinchos presentaron una composición nutricional similar para todas las variables analizadas $(P<0.05)$. Un resultado similar se observó al comparar entre las especies consumidas a excepción del contenido de energía calórica, el cual fue significativamente mayor en aquellas especies consumidas en una proporción mayor que lo disponible $(P<0.05)$. El contenido de agua fue mínimo en las especies consumidas en mayor proporción que lo disponible y máximo en las no consumidas. No se encontraron diferencias significativas entre las gramíneas consumidas y el resto de las especies vegetales consumidas para ninguna de las variables analizadas. La selección de la dieta del carpincho en el área de estudio puede estar relacionada solo de manera parcial con la calidad nutricional, y habría otros factores involucrados en los patrones de forrajeo observados tales como mecanismos fisiológicos del animal o características químicas y estructurales del alimento.

Key Words: diet, forage preference, nutritional benefits hypothesis, wetlands

\section{INTRODUCTION}

Correspondence: María José Corriale, Grupo de Investigaciones sobre Ecología de Humedales, Laboratorio de Ecología Regional, Departamento de Ecología, Genética y Evolución, FCEyN, UBA, Pab II, Ciudad Universitaria, C1428EHA Buenos Aires, Argentina. Email: mjcorriale@ ege.fcen.uba.ar

Manuscript received 1 February 2010; manuscript accepted 23 December 2010.
Food characteristics influence diet selection, and the preference for certain food items may result from their chemical composition, changes in availability, and foraging cost. Every animal faces the dilemma of obtaining adequate food in terms 
of both quantity and quality to fulfill nutritional requirements (Stephens and Krebs 1986; Grier and Burk 1992). Food preferences originate from the functional interrelationship between taste and postingestive feedback, determined by an animal's physiological condition and a food's chemical characteristics (Provenza 1995, 1996).

Among herbivorous mammals, for example, there are a few species such as the giant panda (Ailuropoda melanoleuca; Schaller et al. 1985) and, probably, the spectacled bear (Tremarctus ornatus; Goldstein, 1990) that exclusively use plant cell contents, and must digest large amounts of plant material at a fast passage rate to offset a relatively low abundance of cell content (Alvarez 2002). Other herbivorous species are fiber eaters, in which digestion of fiber is accomplished by different physiological and behavioral strategies. For example, the processes of rumination or coprophagy involve symbiosis with microorganisms providing the enzymes required for fiber degradation (Hume and Warner 1980; Van Soest 1982). Consequently, the preference for a given diet may depend not only on its chemical composition but also on the strategy of the consumer species, such as in the capybara (Hydrochoerus hydrochaeris).

The large rodent capybara is a selective herbivore strongly associated with the land-water interface (González Jiménez and Escobar 1977; Merino and Beccaceci 1995; Quintana 1996, 2002). It is a leaf-eater that consumes low herbaceous plants, with Poaceae and Cyperaceae species as the staple diet items (Ojasti 1973; Escobar and González Jiménez 1976; Quintana et al. 1994, 1998a, 1998b; Barreto and Quintana 2011). Capybaras behave as optimal consumers, selecting high-quality forage during the season of food abundance and consuming a higher diversity of plants during the season of food scarcity (Barreto and Quintana, in press). At least 26 plant species have been reported to be consumed by capybaras (mainly Poaceae and Cyperaceae), which are found in different habitats including the savannas of the Venezuelan llanos and the delta of the Paraná River in Argentina. In both of these cases, over $70 \%$ of the diet is composed of up to five species (Barreto and Quintana in press). In the Pantanal region of Brazil, which harbors large capybara populations, Pott et al. (1986) point out that these rodents consume a medium to high proportion of Cyperaceae species throughout the year. In this same country, Creed (2004) mentions capybara grazing on the submerged marine angiosperm Ruppia maritima, and periods of grazing on land alternating with periods of grazing underwater. In this monogastric animal (Baldizán et al. 1983), fermentation of food is accomplished by cellulose-degrading microorganisms (bacteria, protozoa, and fungi) present in the cecum (González Jiménez 1995). In the capybara, cecotrophy has been recognized as a strategy to increase digestive efficiency (Herrera 1985; Borges et al. 1996). The foraging sites of the capybara are located near the margin of the water body; more distant pastures are unlikely to be used, regardless of their quantity and quality (González Jiménez 1978). In the context of the optimal foraging theory (Stephen and Krebs 1986), the fact that a nearer food source is preferred to a distant one may indicate a trade-off behavior, which results in a more efficient regulation of body temperature in water, and in decreased predation risk. However, the capybara may show a preference for certain Poaceae and Cyperaceae species (Ojasti 1973; Escobar and González Jiménez
1976; Quintana et al. 1994, 1998a, 1998b; Quintana 2002). Such a preference is likely to be explained by the nutritional benefits hypothesis (Gosling 1981; Hobbs and Swift 1988; Guichón et al. 2003), stating that the nutritional value of species consumed in proportion greater than availability by capybaras is higher than that of species consumed in less proportion than availability. Therefore, the objectives of this work are to evaluate the forage quality of the plant species eaten by wild capybara populations in spring in the Lower Delta of the Paraná River, and to test the nutritional benefits hypothesis by analyzing forage quality.

\section{METHODS}

\section{Study Area}

The present study was carried out in two areas located in the insular and noninsular portions of the Lower Delta of the Paraná River, Argentina. The study area is part of the Delta region of the Paraná River, which is a complex macromosaic of different kinds of wetlands (Malvárez 1999) with biogeographic and ecological characteristics unique in the country. Species of subtropical lineage, which penetrate the Delta through the Paraná and Uruguay rivers, coexist with other species from neighboring temperate plains. On the other hand, its high environmental heterogeneity entails an overlapping of different flora and fauna communities reflecting a high biodiversity (Quintana et al. 2002; Kandus et al. 2006).

The region has a subhumid temperate climate with rainfall all year round. Mean annual temperatures are $18^{\circ} \mathrm{C}$ and $16.7^{\circ} \mathrm{C}$ in the northern and southern sections, respectively, and total annual precipitation is approximately $1000 \mathrm{~mm}$ (Servicio Meteorológico Nacional 1992). The Lower Delta (lat 33⒋ ${ }^{\prime} \mathrm{S}$ to lat $34^{\circ} 26^{\prime} \mathrm{S}$, long $59^{\circ} 00^{\prime}$ to long $58^{\circ} 31^{\prime} \mathrm{W}$ ) is the last segment of this region, and stretches through the final $300 \mathrm{~km}$ of the Paraná River basin.

The landscape of the insular area at the Lower Delta is characterized by a mosaic created by afforestations of Salicaceae (Salix spp. and Populus spp.), levees, a dense network of ditches and channels connected to the natural hydrographic network, and patches of the original Scirpus giganteus freshwater marsh. In this area the study was carried out on lands owned by the "San Justo" and "Deltarbor" timber

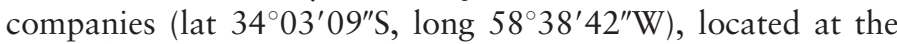
intersection of the Paraná Guazú and Paraná Miní rivers, which covers an area of approximately 8000 ha (Quintana et al. 2005). The landscape of the noninsular area consists of flooded lowlands with freshwater marshes dominated by Schoenoplectus californicus and Hymenachne grumosa; midslopes dominated by grasses such as Cynodon dactylon, Polypogon monspeliensis, and Luziola peruviana; and higher sandy ridges with open forests of Acacia caven. In some cases, the flooded lowlands have free water in their central areas, while the river beds, located along the sandy ridges, are largely covered with floating and rooted aquatic species. In this area the study was carried out in a cattle farm of about 700 ha, located in Puerto Constanza (lat $34^{\circ} 48^{\prime} 30^{\prime \prime} \mathrm{S}$, long $58^{\circ} 58^{\prime} 76^{\prime \prime} \mathrm{W}$ ), in the Department "Islas del Ibicuy," Province of Entre Ríos (Quintana et al. 2005). Table 1 shows the percentage of area occupied by different plant communities in both study areas. Capybaras 
Table 1. Percentage of area occupied by different habitat types $(0 A)$ and frequency of occurrence (FO) of capybara's tracks observed in the different habitat types in both insular (IALD) and noninsular (NIALD) areas of the Lower Delta of the Paraná River (Source: Quintana 1999).

\begin{tabular}{lccc}
\hline & Habitat type $^{1}$ & OA $(\%)^{2}$ & FO $(\%)$ \\
\hline IALD & YPP & 1.55 & 0.0 \\
& MPP & 6.88 & 2.0 \\
& ALE & 7.02 & 87.0 \\
YBA & 0.55 & 0.0 \\
MBA & 0.67 & 3.0 \\
YWP & 7.03 & 66.0 \\
MWP & 51.68 & 7.7 \\
& FWM & 17.22 & 85.0 \\
PDA & 0.42 & 0.0 \\
& D\&C & 6.99 & - \\
SR & 4.47 & 90.0 \\
GR & 24.72 & 0.0 \\
FWMSC & 52.31 & 4.0 \\
FWMHG & 8.85 & 79.0 \\
WC & 9.65 & -
\end{tabular}

1YPP indicates young poplar plantation; MPP, mature poplar plantation; ALE, artificial levees; YBA, young forest of "black acacia" (Gleditsia triacanthos); MBA, mature forest of "black acacia"; YWP, young willow plantation; MWP, mature willow plantation; FWM, freshwater marsh; PDA, peridomestic area; D\&C, ditches and channels; SR, sandy ridge; GR, grassland; FWMSC, freshwater marsh of Schoenoplectus californicus; FWMHG, freshwater marsh of Hymenachne grumosa; WC, water courses.

${ }^{2}$ Frequency of occurrence of capybara tracks was estimated considering number of points with capybara tracks over 100 random points along a transect in each habitat type.

usually use habitat types that provide good conditions for shelter and refuge or are located next to the water courses (Table 1).

\section{Selection of Plant Species}

Data on botanical composition of capybaras' diet in the study areas was obtained from previous studies (Quintana et al. 1994, 1998; Quintana 1996). In those studies, diet composition of this rodent was determined using a microhistological analysis of feces, which were seasonally collected. In addition, a Type I sampling design was developed for the study of diet selection (Thomas and Taylor 1990, 2006), with forage availability and use being estimated at a population level for the entire study area, without identifying particular individuals. In the present study, samples of plant species that were previously identified as consumed in proportion greater than, less than, and according to availability in spring (Quintana 1996, 2002) were collected in the same sites where fecal samples were picked up in order to obtain a representative sample of selected plants for each site. Plant samples were gathered during a 2-wk period in midspring of 1995 in order to evaluate forage quality. We also collected plant species that are very abundant in the field but absent in the diet of capybaras; some of these plants are consumed by other native herbivores such as coypus (Myocastor coypus; Table 2; Quintana 2002; Guichon et al. 2003) for comparing forage quality in both plant groups (consumed vs. not consumed). In both study areas samples of plants were collected from those habitat types used by capybaras (see Table 1) in proportion to its abundance (Quintana 1999). Plant samples were clipped at ground level, according to the forage behavior of capybara, and saved in paper bags for subsequent transfer to the laboratory. We prepared a composite sample of each plant species, which was considered as representative of the whole area and $100 \mathrm{~g}$ were taken for further analysis of forage quality. For Hymenache grumosa and Zizaniopsis bonariensis, we only considered for this analysis leaves located at a height of less than $1 \mathrm{~m}$ because capybaras do not consume the tallest leaves of these plants. Similarly, for this analysis we only considered the H. grumosa leaves; we discarded their stems, which are not consumed by this species.

\section{Forage Quality Analysis}

The forage quality of all sampled species was analyzed by estimating the following variables: water content, ash percentage (total minerals; AOAC 1984), percentage of organic matter, acid detergent fiber as an indicator of digestibility level of plant tissues based on the methodology of Van Soest et al. (1991), nitrogen percentage, crude protein (Kjeldahl; $\mathrm{N} \times 6,25$ method), and caloric energy $\left(\mathrm{Kcal} \cdot \mathrm{Kg} \mathrm{DM}^{-1}\right)$, determined by a Gallenkamp (CB 370) ballistic bomb calorimeter, and the protein to fiber ratio. The last variable was calculated using the crude protein data. Water content was determined by the difference in the weights of the samples before and after drying at $105^{\circ} \mathrm{C}$ for $48 \mathrm{~h}$ in an oven with forced-air circulation. Subsequently, individual samples were ground, and the analysis of chemical composition was made at the Laboratorio de Fitoquímica, IADIZA-CONICET (Mendoza, Argentina).

Each variable was compared between consumed and unconsumed plant species; among species consumed greater than, less than, or according to availability; and between consumed Poaceae and the rest of the consumed plants (Salviniaceae, Cyperaceae, Apiaceae, and Juncaceae). Comparisons were performed using the Kruskal-Wallis test, followed by a posteriori multiple comparisons (Daniel 1978). Student's $t$ test was used for pairwise comparisons when the values of quality variables satisfied the assumption of normality (Zar 1996).

\section{RESULTS}

Table 2 shows the quality variables of the analyzed plant species. The highest protein value corresponded to a Fabaceae species (Trifolium repens), whereas the highest organic matter content was found in two Cyperaceae (Cyperus virens and Carex fuscula) and one Juncaceae (Juncus sp.). The least digestible species were Pontederia cordata, Limnobium laevigatum, and Zizaniopsis bonariensis, with acid detergent fiber values higher than $41 \%$, and the most digestible species were Juncus sp., Hymenachne grumosa, Dichondra microcalyx, and Eleusine tristachya, with acid detergent fiber values between $36 \%$ and $37 \%$.

The species consumed and not consumed by capybaras had a similar forage quality for all the variables analyzed $(P<0.05$; Table 3). A similar result was observed when comparing within consumed species, except for the caloric energy content, which was significantly higher in species consumed in greater proportion than availability than in species consumed in less proportion than availability and consumed according to availability $(P<0.05$; Table 4$)$. The plant species consumed 
Table 2. Nutritional analysis of the main plant species consumed and not consumed by capybara in the Lower Delta of the Paraná River.

\begin{tabular}{|c|c|c|c|c|c|c|c|c|c|c|}
\hline $\mathrm{FR}^{1,2}$ & Species & $\mathrm{F}$ & WC $(\%)$ & AS $(\%)$ & OM $(\%)$ & ADF $(\%)$ & $\mathrm{N}(\%)$ & $\mathrm{CP}(\%)$ & $\begin{array}{c}\mathrm{CE}(\mathrm{Kcal} \cdot \mathrm{kg} \\
\left.\mathrm{DM}^{-1}\right)\end{array}$ & $\begin{array}{c}C P: A D F \\
\text { ratio }\end{array}$ \\
\hline \multirow[t]{4}{*}{$\mathrm{C}_{\mathrm{AA}}$} & Salvinia rotundifolia & $S$ & 94.06 & 26.52 & 73.47 & 40.28 & 2.38 & 14.87 & 3985 & 0.37 \\
\hline & Zizaniopsis bonariensis & $P$ & MD & 12.89 & 87.1 & 41.56 & 2.1 & 13.12 & 4006 & 0.32 \\
\hline & Cyperus virens & C & 64.8 & 8.48 & 91.52 & 38.45 & 1.26 & 7.87 & 3917 & 0.20 \\
\hline & Juncus spp. & J & 64.22 & 7.9 & 92.02 & 37.05 & 1.19 & 7.43 & 3876 & 0.20 \\
\hline \multirow[t]{2}{*}{$C_{L A}$} & Oplimenopsis najada & $P$ & 86.73 & 10.89 & 89.1 & 38.24 & 2.24 & 14 & 3882 & 0.37 \\
\hline & Paspalum dilatatum & $P$ & 70.8 & 13.62 & 86.18 & 40.98 & 2.1 & 13.12 & 4120 & 0.32 \\
\hline \multirow[t]{3}{*}{$\mathrm{C}_{\mathrm{GA}}$} & Carex fuscula & C & 42.23 & 8.98 & 91.02 & 40.16 & 1.36 & 8.5 & 4197 & 0.21 \\
\hline & Hymenachne grumosa & $P$ & 76.8 & 10.64 & 89.36 & 37.02 & 1.52 & 9.5 & 4386 & 0.26 \\
\hline & Cynodon dactilon & $P$ & 74.31 & 11.45 & 88.55 & 37.86 & 1.8 & 11.25 & 4202 & 0.30 \\
\hline \multirow[t]{5}{*}{ NC } & Limnobium laevigatum & $\mathrm{H}$ & 88.65 & 21.43 & 78.57 & 41.05 & 2.24 & 14 & 3991 & 0.34 \\
\hline & Panicum milioides & $P$ & MD & 11.74 & 88.26 & 37.29 & 1.96 & 12.25 & 3850 & 0.33 \\
\hline & Hidrocotile spp. & A & 85.14 & 17.32 & 82.68 & 38.15 & 2.38 & 14.87 & 3896 & 0.39 \\
\hline & Pontederia cordata & Po & 77.72 & 12.19 & 87.81 & 43.1 & 1.54 & 9.62 & 4136 & 0.22 \\
\hline & Eichornia crassipes & Po & 81.55 & 14.17 & 85.83 & 39.06 & 1.61 & 10.06 & 4019 & 0.26 \\
\hline
\end{tabular}

${ }^{1}$ Based on data by Quintana (1996, 2002).

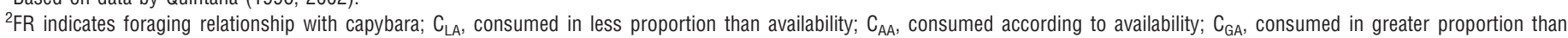
availability; F, family; S, Salvinaceae; P, Poaceae; C, Cyperaceae; J, Juncaceae; H, Hydrocharitaceae; Fa, Fabeaceae; A, Apiaceae; Po, Pontederiaceae; NC, not consumed; WC, water content; AS, ashes; OM, organic matter; ADF, acid detergent fiber; N, nitrogen; CP, crude protein; CE, caloric energy; DM, dry matter; MD, missing data.

in greater proportion than availability showed a tendency to have a higher percentage of organic matter than the remaining categories. Water content was at its minimum in species consumed in greater proportion than availability, increased gradually in species used according to availability and in less proportion than availability (Table 4), and was at its maximum in unconsumed species (Table 3). No significant differences were found between consumed Poaceae and the rest of the consumed plant species for any of the analyzed variables (Table 5).

\section{DISCUSSION}

Our results indicate that capybaras from the Lower Delta of the Paraná River would select certain plant species according to a particular nutritional feature (caloric energy content). If the forage value of a plant species is defined in terms of protein and energy richness (Zea and Díaz 2000), the nutritional-benefits hypothesis is partially supported because plant species selected by capybaras differ from the rest only in having higher energy content.

In contrast to observations in other studies (Barreto and Herrera 1998, Alvarez 2002), capybaras from the studied area do not appear to consume plant species maximizing quality variables considered to play a critical role in diet selection, such as the protein to fiber ratio, and the nitrogen and crude protein contents (Ojasti 1973; González Jiménez 1978; Milton 1979; Baker and Hobbs 1982; Somlo et al. 1985; San Martín 1991; Genin et al. 1995; Wasserman and Chapman 2003). In this context, the cecotrophy observed in capybaras (Herrera 1985)

Table 3. Comparison of mean values of quality variables (QV) between plant species consumed and not consumed by capybaras in Lower Delta of the Paraná River. The values within brackets indicate the range for each variable. ${ }^{1}$

\begin{tabular}{|c|c|c|c|c|c|}
\hline QV & C & NC & Statistic & $\mathrm{df}$ & $P^{2}$ \\
\hline WC (\%) & $70.59(42.23-94.06)$ & $80.67(69.43-88.65)$ & $t=-1.764$ & 15 & 0.098 \\
\hline AS (\%) & $11.45(8.98-13.62)$ & $15.11(10.08-21.43)$ & $\mathrm{H}=2.46$ & 17 & 0.117 \\
\hline OM (\%) & $87.1(73.47-92.02)$ & 84.89 (78.57-89.92) & $t=0.995$ & 17 & 0.334 \\
\hline $\operatorname{ADF}(\%)$ & $39.0(37.02-41.56)$ & $38.97(36.41-43.1)$ & $t=0.032$ & 17 & 0.975 \\
\hline N (\%) & $1.89(1.19-2.4)$ & $2.2(1.54-3.08)$ & $t=-1.36$ & 17 & 0.192 \\
\hline CP $(\%)$ & $11.78(7.43-15)$ & $13.72(9.62-19.25)$ & $t=-1.36$ & 17 & 0.192 \\
\hline $\mathrm{CE}\left(\mathrm{Kcal} \cdot \mathrm{Kg} \mathrm{DM}^{-1}\right)$ & 4058 (3 876-4 386) & 4076 (3 850-4 636) & $t=-0.187$ & 17 & 0.854 \\
\hline CP:ADF ratio & $0.30(0.2-0.39)$ & $0.35(0.22-0.28)$ & $t=-1.432$ & 17 & 0.17 \\
\hline
\end{tabular}

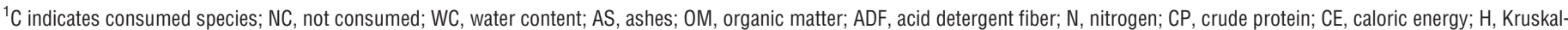
Wallis statistic; $t$, Student's statistic; df, degrees of freedom; $P$, statistical probability; DM, dry matter.

${ }^{2}$ All differences are statistically nonsignificant. 
Table 4. Comparison of mean values of quality variables $(\mathrm{QV})$ among plant species consumed in less proportion than availability $\left(\mathrm{C}_{\mathrm{LA}}\right)$, consumed according to availability $\left(\mathrm{C}_{\mathrm{AA}}\right)$, and consumed in greater proportion than availability $\left(\mathrm{C}_{\mathrm{GA}}\right)$ by capybaras in the Lower Delta of the Paraná River. The values within brackets indicate the range for each variable. ${ }^{1}$

\begin{tabular}{|c|c|c|c|c|c|}
\hline QV & $C_{L A}$ & $\mathrm{C}_{\mathrm{AA}}$ & $\mathrm{C}_{\mathrm{GA}}$ & $\mathrm{H}$ & $P$ \\
\hline WC (\%) & $74.36(64.22-94.06)$ & $72.38(64.97-86.73)$ & 64.45 (42.23-76.8) & 0.20 & 0.905 \\
\hline AS (\%) & $13.95(7.9-26.52)$ & $13.68(10.89-17.16)$ & $10.36(8.98-11.45)$ & 2.42 & 0.299 \\
\hline OM (\%) & 86.03 (73.47-92.02) & 86.27 (82.84-89.10) & 89.64 (88.55-91.02) & 2.42 & 0.298 \\
\hline ADF $(\%)$ & $39.34(37.05-41.56)$ & $39.14(38.14-40.98)$ & $38.35(37.02-40.16)$ & 1.55 & 0.462 \\
\hline N (\%) & $1.73(1.19-2.38)$ & $2.28(2.1-2.4)$ & $1.56(1.36-1.8)$ & 4.45 & 0.108 \\
\hline $\mathrm{CP}(\%)$ & $10.82(7.43-14.87)$ & $14.25(13.12-15)$ & $9.75(8.5-11.25)$ & 4.45 & 0.108 \\
\hline $\mathrm{CE}\left(\mathrm{Kcal} \cdot \mathrm{Kg} \mathrm{DM}{ }^{-1}\right)$ & 3946 (3 876-4 006) & 4018 (3 882-4 133) & 4261.67 (4 197-4 386) & 6.41 & $0.041^{2}$ \\
\hline CP:ADF ratio & $0.27(0.2-0.37)$ & $0.36(0.32-0.39)$ & $0.26(0.21-0.3)$ & 5.18 & 0.075 \\
\hline
\end{tabular}

${ }^{1}$ WC indicates water content; AS, ashes; OM, organic matter; ADF, acid detergent fiber; $\mathrm{N}$, nitrogen; $\mathrm{CP}$, crude protein; $\mathrm{CE}$, caloric energy; $\mathrm{H}$, Kruskal-Wallis statistic; $P$, statistical probability; DM, dry matter.

${ }^{2}$ Statistically significant difference.

would allow more efficient exploitation of forage. In Venezuela, for example, cecotrophy is more frequent during periods of drought, when food is scarce and poor in nutrients (Herrera 1985; Borges et al. 1996). Experiments in captivity showed that capybaras fed low-protein diets exhibited cecotrophy, but that this behavior was not observed in animals fed nitrogen-rich diets (González Jiménez et al. 1976; Mendes et al. 2000; Alvarez 2002). Thus, this facultative behavior may represent a strategy through which capybaras meet their protein requirements even if the diet is protein deficient (Herrera 1985; Borges et al. 1996; Mendes et al. 2000).

In the study area, plant species not consumed by capybaras but abundant in the field had slightly higher nitrogen content than consumed species, although this difference was not statistically significant. In captivity, capybaras prefer forage with high crude protein and organic matter contents, and high protein to fiber ratio (Alvarez 2002). In nature, it is possible that factors other than nitrogen content may play a role in diet selection.

Energy content seemed to be the only variable on which capybaras based food selection. High-energy foods would not only be selected for weight gain and maintenance, but also to improve health status, as indicated by decreased morbidity and mortality rates in captive capybaras (Andrade et al. 1998). On the other hand, no differences in body weight gain, feed intake, or feed conversion ratio were detected between animals fed with high- or low-protein diets (Silva Neto 1989; Andrade et al.
1998). This agrees with the optimal foraging theory, which is mainly based on the assumption that natural selection will favor individuals maximizing net rate of energy intake (Schoener 1971; Pyke et al. 1977; Krebs et al. 1981). However, some authors (Pulliam 1975; Belovsky 1978) have pointed out that forage quality is so variable that maximizing the net rate of energy intake is unlikely to be one of the main goals for most herbivores. The fact that in this work capybaras consumed high-energy-content items and previous studies showed that they have a selective foraging behavior (Ojasti 1973; González Jiménez and Escobar 1977; Quintana 2002) may suggest that, in contrast to other herbivores, capybaras behave so as to maximize energy intake.

Although water content did not differ significantly among any of the four plant categories, there was a tendency toward an inverse relationship between foraging preference and water content. Foods with low water content may decrease retention time, thus leading to an increased digestive rate (Alvarez 2002). This, together with the fact that food intake decreases with increased energy content (Alvarez 2002), would reduce the time spent in foraging. As a result, capybaras would have more time for vigilance, thereby decreasing predation risk (MacDonald 1981; Senar 1994; Alvarez 2002). This behavior, which could be looked upon as an antipredator strategy, is particularly useful for medium-sized and large herbivores that require a high daily food intake, being at the same time aware of predators.

Table 5. Comparison of mean values of quality variables (QV) between consumed Poaceae species and the other species consumed by capybaras in the Lower Delta of the Paraná River. The values within brackets indicate the range for each variable. ${ }^{1}$

\begin{tabular}{lcccc}
\hline \multicolumn{1}{c}{ QV } & Poaceae & Other plant species & $H$ & $P^{2}$ \\
\hline WC (\%) & $74.7(65-86.7)$ & $66.5(42.23-94.06)$ & 1.84 & 0.175 \\
AS (\%) & $12.1(10.6-13.6)$ & $74.7(65-86.7)$ & 0.30 & 0.584 \\
OM (\%) & $87.9(86.1-89.4)$ & $86.2(73.5-92)$ & 0.30 & 0.03 \\
ADF (\%) & $39.1(37-41.6)$ & $38.8(37.1-40.3)$ & 0.41 & 0.854 \\
N (\%) & $2.02(1.52-2.38)$ & $1.7(1.19-2.4)$ & 0.41 & 0.520 \\
CP (\%) & $12.6(9.5-14.87)$ & $10.7(7.43-15)$ & 2.13 & 0.521 \\
CE (Kcal· Kg DM & & \\
CP:ADF ratio & $4121.5(3882-4386)$ & $3982.4(3876-4197)$ & 0.53 & 0.144 \\
\hline
\end{tabular}

${ }^{1}$ WC indicates water content; AS, ashes; OM, organic matter; ADF, acid detergent fiber; $\mathrm{N}$, nitrogen; $\mathrm{CP}$, crude protein; $\mathrm{CE}$, caloric energy; $\mathrm{H}$, Kruskal-Wallis statistic; $P$, statistical probability; DM, dry matter.

${ }^{2}$ All differences are statistically nonsignificant. 
Poaceae are usually considered to have a high foraging value (Sotomayor Ríos 1973; Aguilar et al. 1995; Genin et al. 1995) and are consumed in greater proportion than availability by the capybara (Ojasti 1973; Escobar and González Jiménez 1976; Quintana et al. 1994; Quintana 2002). In the present paper, mean crude protein and nitrogen values were slightly higher in this plant group than in the other two groups of consumed species, although the differences were not statistically significant. On the other hand, the crude protein content in capybara's diet was similar to that reported by Ojasti (1973) in Venezuelan plains.

It must be taken into account that the nutritional value of a certain food depends not only on its chemical composition, but also on the interaction among its chemical composition, its physical structure, and the ability of the animal to digest and process the food (Haufler and Servello 1996). In addition, there are other factors known to affect food selection, such as the physical and chemical defenses of plants (Freeland and Janzen 1974) and their organoleptic properties (Westoby 1974), which were not included in our analysis but could play an important role in the observed foraging patterns.

\section{MANAGEMENT IMPLICATIONS}

In conclusion, diet selection by capybaras in the Lower Delta of the Paraná River may only be partially related to forage quality, and there could be other factors involved in foraging, such as physiological mechanisms of the animal or chemical and structural characteristics of food (Bozinovic and Martínez del Río 1996). Therefore, further studies on other parameters associated with physiological mechanisms such as digestibility and efficiency of use of chemical components would be useful for a better understanding of the process of foraging by capybaras.

In Argentina, capybara is one of the most heavily exploited native species and management plans are currently being designed for the sustainable use of wild populations. In the Lower Delta of the Paraná River, as in other regions of the country, capybaras are used by local communities as an additional protein source and for hide trade. Therefore, the knowledge of the forage value of capybara's diet serves as a basis for future management actions in the Paraná River delta. Here, the habitats of this species are under strong anthropogenic pressure from two important productive activities: cattle raising and Salicaceae afforestations. The former has led to considerable overgrazing and trampling, resulting in a negative impact on the composition and abundance of natural vegetation, whereas the latter has modified wetlands causing the replacement of native vegetation. Consequently, the evaluation of the forage value of native and naturalized plant species in these threatened environments is also of great importance in designing strategies for the preservation of capybara's habitats, which, in turn, will help to maintain some of the economic activities undertaken by local inhabitants.

\section{ACKNOWLEDGMENTS}

The authors are grateful to Dr Mario Mederos and the Laboratorio de Fitoquímica, IADIZA-CONICET (Mendoza, Argentina) for sample anal- ysis. Special thanks to S. Pietrokovsky for her invaluable help with the English translation and C. Rossi for his suggestions. Research was funded by grants X-817 and X-481 (UBACyT) from the University of Buenos Aires, and PICT 1849 from the FONCyT (Agencia de Promoción Científica y Tecnológica), Argentina.

\section{LITERATURE CITED}

Aguilar, M. G., G. Martín, R. Neumann, and E. P. Chagra Dib. 1995. Estimación de la composición botánica en la dieta de la vicuña (Vicugna vicugna) en la puna jujeña. Revista Argentina de Producción Animal 15:343-346.

Alvarez, M. R. 2002. Manejo sustentable del carpincho (Hydrochoerus hydrochaeris, Linnaeus 1766) en Argentina: un aporte al conocimiento de la biología de la especie desde la cría en cautiverio [PhD thesis]. Buenos Aires, Argentina: Universidad de Buenos Aires. 139 p.

Andrade, P. C., A. Lavorenti, and S. L. Nogueira-Filho. 1998. Effects of the size of area, of the diet and of the initial age of confinement on capybaras growth (Hydrochoerus hydrochaeris L. 1766). Brazilian Journal of Animal Science 27:292-299.

AOAC. 1984. Standard official methods of analysis of the Association of Analytical Chemists. 14th edition. S. W. Williams [ed.]. Washington, DC, USA: Association of Analytical Chemists. $121 \mathrm{p}$.

BAKER, D. L., AND N. T. HoBBs. 1982. Composition and quality of elk summer diets in Colorado. Journal of Wildlife Management 46:694-703.

Baldizán, A., R. M. Dixon, and R. Parra. 1983. Digestion in the capybara (Hydrochoerus hydrochaeris). South Africa Journal of Animal Science 13:27-28.

Barreto, G. R., and E. A. Herrera. 1998. Foraging patterns of capybaras in a seasonally flooded savanna of Venezuela. Journal of Tropical Ecology 14:87-98.

Barreto, G., And R. D. Quintana. 2011. Feeding habits of capybara. In: J. R. Moreira, K. M. P. Ferraz, E. A. Herrera, and D. W. Macdonald [EDS.], Capybara: biology, use and conservation. Dordrecht, the Netherlands: Springer (in press).

Belovsky, G. E. 1978. Diet optimization in a generalist herbivore: the moose. Theoretical Population Biology 14:105-134.

Borges, P. A., M. G. Dominguez-Bello, and E. A. Herrera. 1996. Digestive physiology of wild capybara. Journal of Comparative Physiology 166:55-60.

Bozinovic, F., And C. Martínez del Río. 1996. Animals eat what they should not: why do they reject our foraging models? Revista Chilena de Historia Natural 69:15-20.

CreED, J. C. 2004. Capybara (Hydrochaeris hydrochaeris Rodentia: Hydrochaeridae): a mammalian seagrass herbivore. Estuaries 27:197-200.

DanieL, W. W. 1978. Applied nonparametric statistics. Boston, MA, USA: Houghton Mifflin Company. 503 p.

Escobar, A., and E. Gónzalez-Jiménez. 1976. Estudio de la competencia alimenticia de los herbívoros mayores del Llano inundable con referencia especial al chigüiro (Hydrochaerys hydrochaeris). Agronomía Tropical 26:215-227.

Freeland, W. J., AND D. H. Janzen. 1974. Strategies in herbivory by mammals: the role of plant secondary compounds. American Naturalist 108:269-289.

Genin, D. P., M. Abasto, And M. Tichit. 1995. Composición química y degradabilidad de forrajes natives. II. Comportamiento alimenticio. In: Revista Waira Pampa. Un sistema pastoril camélidos-ovinos del altiplano árido boliviano. Oruro, Bolivia: ORSTOM. COMPAC-Oruro-IBTA. p. 131-142.

GoldsteIn, I. 1990. Distribución y hábitos alimenticios del oso frontino, Tremarctos ornatus, en Venezuela [MSc thesis]. Caracas, Venezuela: Universidad Simón Bolívar. $164 \mathrm{p}$.

González Jiménez, E. 1978. Digestive physiology and feeding of capybara (Hydrochoerus hydrochaeris). In: M. Rechcigl [ED.]. Handbook series in nutrition and food. Cleveland, OH, USA: CRC Press. p. 163-177.

González JimÉnEZ, E. 1995. El capibara (Hydrochoerus hydrochaeris). Estado actual de su producción. Rome, Italy: Estudio FAO Producción y Sanidad Animal no. $122.112 \mathrm{p}$.

González Jiménez, E., and A. Escobar. 1977. Flood adaptation and productivity of savanna grasses. In: Proceedings XIII International Grassland Congress, 
Leipzig, German Democratic Republic, 18-27 May 1977. Berlin, Germany: Leipzig Akademic Verlag. p. 510-514.

González Jiménez, E., A. Escobar, and 0. Caires. 1976. Un metodo para detectar coprofagia en chigüires: resultados. In: Resúmenes del II seminario sobre chigüires y babas; 1-4 December 1976; Maracay, Venezuela. Maracay, Venezuela: CONICIT I.P.A. Fac.Agron. U.C.V. p. 2-3.

GosLing, L. M. 1981. Climatic determinants of spring littering by feral coypus, Myocastor coypus. Journal of Zoology 195:281-288.

Grier, J. W., AND T. Burk. 1992. Biology of animal behaviour. 2nd ed. St. Louis, MO, USA: Mosby Year Book. 890 p.

Guichón, M. L., V. B. Benítez, A. Aвba, M. Borgnia, and M. H. Cassinı. 2003. Foraging behaviour of coypus Myocastor coypus: why do coypus consume aquatic plants? Acta Oecologica 24:241-246.

Haufler, J. B., and F. A. Servello. 1996. Techniques for wildlife nutritional analyses. In: T. A. Bookout [ED.]. Research and management techniques for wildlife and habitats. Bethesda, MD, USA: The Wildlife Society. p. 307-323.

Herrera, E. A. 1985. Coprophagy in capybara, Hydrochoerus hydrochoeris. Journal of Zoology 217:616-619.

HoBBS, N. T., AND D. M. SwIFt. 1988. Grazing in herds: when are nutritional benefits realized? American Naturalist 131:760-764.

Hume, I. D., and A. C. I. Warner. 1980. Evolution of microbial digestion in mammals. In: Y. Ruckebusch and P. Thivend [EDS.]. Digestive physiology and metabolism in ruminants. Westport, CT, USA: AVI. p. 665-684.

Kandus, P., R. D. Quintana, and R. Bó. 2006. Patrones de paisaje y biodiversidad del Bajo Delta del Río Paraná. Mapa de Ambientes. Buenos Aires, Argentina: Pablo Casamajor Ediciones. 40 p.

Krebs, J. R., A. I. Houston, and E. L. Charnov. 1981. Some recent developments in optimal foraging. In: A. C. Kamil and T. D. Sargent [EDS.]. Foraging behaviour. New York, NY, USA: Garland STPM Press. p. 3-18.

MACDonald, D. 1981. Dwindling resources and the social behaviour of capybaras (Hydrochoerus hydrochaeris) (Mammalia). Journal of Zoology 194:371-391.

Malvárez, A. I. 1999. El Delta del Río Paraná como mosaico de humedales. In: A. I. Malvárez [ED.]. Tópicos sobre humedales subtropicales y templados de Sudamérica. Montevideo, Uruguay: Oficina Regional de Ciencia y Técnica para America Latina y el Caribe (ORCyT) MAB/UNESC0. p. 35-54.

Mendes, A., S. S. C. Nogueira, A. Lavorenti, and S. L. G. Filho. 2000. A note on the cecotrophy behavior in capybara (Hydrochaeris hydrochaeris). Applied Animal Behaviour Science 66:161-167.

Merino, M. L., and M. D. BeccaceCl. 1995. Relación trófica entre el ciervo de los pantanos Blastocerus dichotomus Illiger 1815 y el carpincho Hydrochaeris hydrochaeris Linnaeus 1766 en la Reserva "Iberá", Corrientes, Argentina. In: Resúmenes del III Congreso Latinoamericano de Ecología; 22-28 October 1995; Mérida, Venezuela. Mérida, Venezuela, p. 24-13.

MILToN, K. 1979. Factors influencing leaf choice by howler monkeys: a test of some hypotheses of food selection by generalist herbivores. American Naturalist 114:363-378.

OJASTI, J. 1973. Estudio biológico del chigüire o capibara. Caracas, Venezuela: Fondo Nacional de Investigaciones Agropecuarias (FONAIAP). $275 \mathrm{p}$.

Pott, A., Z. Campos, and C. Alho. 1986. Plantas da dieta da capivara de Nhecolandia, Pantanal; observaçoes iniciais. In: Resumos da Congresso Nacional de Botanica. Ouro Preto, Brazil, 27. p. 262.

Provenza, F. D. 1995. Postingestive feedback as an elemental determinant of food preference and intake in ruminants. Journal of Range Management 48:2-17.

ProvenzA, F. D. 1996. Acquired aversions as the basis for varied diets of ruminants foraging on rangelands. Journal of Animal Science 74:2010-2020.

Pulclam, H. R. 1975. Diet optimization with nutrient constraints. American Naturalist 109:765-768.

Pyke, G. H., H. R. Pulliam, and E. L. Charnov. 1977. Optimal foraging: a selective review of theory and tests. Quarterly Review of Biology 52:137-154.

Quintana, R. D. 1996. Análisis y evaluación del hábitat del carpincho (Hydrochaeris hydrochaeris) en relación con la heterogeneidad del paisaje y las interacciones con el Ganado doméstico [PhD thesis]. Buenos Aires, Argentina: Universidad de Buenos Aires. 273 p.

QuintanA, R. D. 1999. Relación entre la estructura del paisaje en un humedal y la fauna silvestre: el carpincho (Hydrochaeris hydrochaeris) como caso de estudio. In: A. I. Malvárez [ed.]. Tópicos sobre humedales subtropicales y templados de Sudamérica. Montevideo: ORCyT — MAB/UNESCO. p. 185-204.

QuintanA, R. D. 2002. Influence of livestock grazing on the capybara's trophic niche and forage preferences. Acta Theriologica 47:175-183.

Quintana, R. D., R. F. Bó, And F. Kalesnik. 2002. La vegetación y la fauna silvestres de la porción terminal de la Cuenca del Plata. Consideraciones biogeográficas y ecológicas. In: J. M. Bortharagay [ED.]. El Río de la Plata como territorio. Buenos Aires, Argentina: Facultad de Arquitectura y Urbanismo, UBA y Ediciones Infinito. p. 99-124.

Quintana, R. D., N. Madanes, A. I. Malvárez, F. A. Kalesnik, and M. Cagnoni. 2005. Caracterización de la vegetación en tres tipos de hábitat de carpinchos en la baja cuenca del Río Paraná, Argentina. Temas de la Biodiversidad del Litoral fluvial argentino II. INSUGEO. Miscelánea 14:83-96.

Quintana, R. D., S. Monge, and A. I. Malvárez. 1994. Feeding habits of capybara (Hydrochaeris hydrochaeris) in afforestation areas of the Lower Delta of the Parana River, Argentina. Mammalia 58:569-580.

Quintana, R. D., S. Monge, and A. I. Malvárez. 1998a. Feeding patterns of capybara Hydrochaeris hydrochaeris (Rodentia, Hydrochaeridae) and cattle in the noninsular area of the Lower Delta of the Paraná River, Argentina. Mammalia 62:37-52.

Quintana, R. D., S. Monge, and A. I. Malvárez. 1998b. Composición y diversidad de las dietas del capibara (Hydrochaeris hydrochaeris) y del ganado doméstico en un agroecosistema del centro de Entre Ríos, Argentina. Ecotrópicos 11:34-44.

San Martín, F. 1991Alimentación y nutrición. In: S. Fernández Baca [ed.]. Avances y perspectivas del conocimiento de los camélidos sudamericanos. Santiago, Chile: Oficina Regional de la FA0 para América Latina y el Caribe, p. 213-261.

Schaller, G. B., H. Jinchu, P. Wenshi, and Z. Jing. 1985. The giant pandas of Wolong. Chicago, IL, USA: University of Chicago Press. 298 p.

SCHoener, T. W. 1971. Theory of feeding strategies. Annual Review of Ecology and Systematics 2:369-404.

Senar, J. C. 1994. Vivir y convivir: la vida en grupos sociales. In: J. Carranza [ed.]. Etología. Introducción a la ciencia del comportamiento. Cáceres, Spain: Universidad de Extremadura, Servicio de Publicaciones. p. 205-233.

Servicio Meteorológico Nacional. 1992. Estadísticas climatológicas 1981-1990. Series B6, no. 37. 1st ed. Buenos Aires, Argentina: Fuerza Aérea Argentina. $704 \mathrm{p}$.

Silva Neto, P. B. 1989. Alimentação e manejo de capivaras (Hydrochoerus hydrochaeris hydrochaeris L. 1766) em cativeiro [MSc thesis]. Piracicaba, Brazil: Escola Superior de Agricultura "Luiz de Queiroz." 99 p.

Somlo, R., C. Durañona, and R. Ortiz. 1985. Valor nutritivo de especies forrajeras patagónicas. Revista Argentina de Producción Animal 5:589-605.

Sotomayor Ríos, A., A. Acosta Matienzo, and J. Velez Fortuno. 1973. Evaluation of seven forage grasses at two cutting stages. Journal of Agronomy University 57:173-182.

Stephens, D. W., and J. R. KreBs. 1986. Foraging theory. Princeton, NJ, USA: Princeton University Press. $261 \mathrm{p}$.

Thomas, D., and E. Taylor. 1990. Study designs and test for comparing resource use and availability. Journal of Wildlife Management 54:332-330.

Thomas, D. L., And E. J. TaYlor. 2006. Study designs and tests for comparing resource use and availability II. Journal of Wildlife Management 70:324-336.

VAN SOEST, P. 1982. Nutritional ecology of the ruminant. Corvallis, OR, USA: DO Books Inc. 374 p.

Van Soest, P. J., J. B. Robertson, and B. A. Lewis. 1991. Methods for dietary fiber, neutral detergent fiber, and non-starch polysaccharides in relation to animal nutrition. Journal of Dairy Science 74:3583-3597.

Wasserman, M. D., and C. A. Chapman. 2003. Determinants of colombine monkey abundance: the importance of food energy, protein and fibre content. Journal of Animal Ecology 72:650-659.

Westoby, M. 1974. An analysis of diet selection by large generalist herbivores. American Naturalist 108:290-304.

ZAR, J. 1996. Biostatistical analysis. 3rd ed. Upper Saddle River, NJ, USA: Prentice-Hall, Inc. 662 p.

ZEA, J., AND D. Díaz. 2000. El pasto y la alimentación del ternero de carne. Mundo Ganadero 118:24-26. 